\title{
Editorial: 1984 and all that
}

Presumably, one of the educational journals remarked, Dr Bernice Martin and Mr Renford Bambrough have been put there to provide the Josephite rigour. The comment greeted the establishment in the autumn of 1984 of the Council for the Accreditation of Teacher Education, a body set up, according to Circular $3 / 84$, 'to advise the Secretaries of State for Education and Science and for Wales on the approval of initial teacher training courses in England and Wales'. The Council at once came to be called CATE, just as the Welsh Office Education Department is familiarly called WOED, pronounced 'woad'.

'The membership of the Council', the Circular continued, 'will be drawn mainly from practising school teachers, teacher trainers and elected members and officers of local education authorities, with the aim of giving the Secretaries of State the benefit of the advice of experienced professionals with a broad knowledge of the best practice in teacher education.' This formulation may well have provoked puzzlement at the inclusion in the list of a sociologist and a philosopher. No surprise was occasioned by the appointment of representatives of industry and commerce, and little if any by that of $\mathrm{Mr}$ Michael Dixon, then Education correspondent of the Financial Times. A rationale or rationalization for the choice of two academics might be that the universities, like industry and commerce, are prime users of the 'product' that is produced by primary and secondary schools. But further factors may well have been taken into account. Much of the work of the Council has required the consideration of conceptual questions, as one might expect of a body charged with the responsibility of interpreting and applying a set of 'criteria'. How, if at all, can the Council's requirement of two years of subject study, 'at a level appropriate to higher education', be reconciled with the relative sharpness of the distinction between academic validation and professional accreditation, which was meant to differentiate the tasks of universities and other validating bodies from those of the Council itself? At a more general level there were the uncertainties that always arise where rules are applied to cases, and matters of principle are raised by complex particularities.

A symptom of these problems was that some critics complained of bureaucratic rigidity in the imposition of a centralized pattern on teacher training courses, while others deplored the lack of firm guidance about what exactly they must do to satisfy the criteria. The outcome shows that a great range of courses can meet the requirement, just as an enormous variety of cars, from the mini to the gas-guzzler, 
from the deux chevaux to the Range Rover, can all meet the statutory tests to which motor vehicles are subject.

It would take an historian-a luxury with which the Council was not provided-to set the full scene for the inauguration of the Council and the specification of its tasks. Even the briefest summary would note that the teaching profession had become recognized as being or needing to be a fully 'graduate profession'. This had to be achieved by raising the academic level of the students and their courses rather than by diluting the notion of a degree. A tendentious but not wholly misleading parallel may be drawn from a question addressed by a school governor to a candidate for appointment as headmaster. 'We all agree', the governor said, 'that there should be complete conformity between the conduct of the boys and the rules of the school. Do you', he went on, 'take the view that this is best achieved by adjusting the rules to fit the conduct or by adjusting the conduct to fit the rules?'

The 'subject studies' criterion has proved to be especially controversial in its application to primary courses. It continues to be assertedand fortunately also continues to be denied - that the academic level of the studies of teachers of very young children need not much exceed that of the children's learning. This time our anecdote may be more tendentious, but again it points at the target. In the early days of BBC schools broadcasting there was a musical programme on Stravinsky's Firebird, at the end of which the presenter invited the children to make and send their own pictures of the Firebird. Within days there was a protest from the Highlands and Islands of Scotland, complaining that once again the BBC was favouring the south of England. How could it be expected that a child born and bred in the Isle of Skye should even have seen a firebird? 